\title{
Genetic diversity in European beech (Fagus sy/vatica L.) seed stands in the Romanian Carpathians
}

\author{
A.-M. Szasz-Len, M. Konnert
}

Szasz-Len, A.-M., Konnert M., 2018. Genetic diversity in European beech (Fagus sylvatica L.) seed stands in the Romanian Carpathians. Ann. For. Res. 61(1): 65-80.

Abstract. In Romania, European beech (Fagus sylvatica L.) is the most important broadleaved tree species. The goal of the present study was to determine the genetic diversity and differentiation in and between natural beech populations from the Romanian Carpathians and the transmission of the genetic diversity to the next generation. The populations analyzed were registered as seed stands. Genetic analysis was based on ten nuclear microsatellites. The highest amount of genetic variation was within populations, whereas genetic differentiation between populations was low. In the adult populations the mean number of alleles per locus varied from 8.0 to 10.9 , the effective number from 8.3 to 9.6 . Heterozygosity ranged from 0.637 to 0.750 with the mean of $0.681( \pm 0.018)$. The overall genetic differentiation $\mathrm{F}_{\mathrm{ST}}$ between populations averaged 0.014. Geographic patterns within this region were not detected. Regenerating these stands naturally has not implied a reduction in the genetic variation in the following generation. Allelic richness, genetic diversity and heterozygosity in adult stands and their natural regeneration is not significantly different. Inbreeding effects were not observed (F between -0.032 and 0.061 ). The results complete the knowledge on genetic variation of beech in Romania and give insides into the genetic diversity of beech seed stands. They can be helpful too for the delineation of provenance regions in the Romanian Carpathians.

Keywords Fagus sylvatica L., genetic diversity, genetic differentiation, seed stand, natural regeneration

Authors. Anna-Maria Szasz-Len (hannasas@gmail.com) - University of Agricultural Sciences and Veterinary Medicine Cluj-Napoca, Calea Manastur 3-5, 400372 Cluj-Napoca, Romania; Monika Konnert - Bavarian Office for Forest Seeding and Planting, 83317 Teisendorf, Sudetenlandstr. 23, Germany.

Manuscript received February 2, 2018; revised June 26, 2018; accepted June 29, 2018; online first July 3, 2018.

\section{Introduction}

In Romania European beech (Fagus sylvatica L.) is the most important broadleaved tree spe- cies in terms of surface area and standing volume covering about 2.125 million ha (Anonymous 2016). The forest area covered by beech is approximately constant over time (Milescu 
et al. 1967, Stănescu 1979). The knowledge about beech population genetics in Romania remains predominantly scanty, although some natural populations have been studied by isozymes within the framework of international studies (Comps et al. 1990, 2001; Gömöry et al. 1999, 2003, 2010; Longauer et al. 2001, 2004; Paule 1995, Paule et al. 2001, Petit et al. 2003, Sulkowska et al. 2012). Beside this, for selected Romanian beech provenances in nursery or field tests, the genetic structure was determined by isozyme analysis (Kim 1985, Konnert \& Ruetz 2001), PCR-RFLP technique and chloroplast microsatellites (Popescu \& Postolache 2009) or nuclear microsatellites (Liesebach 2012, Liesebach et al. 2015). Nuclear microsatellites were also used to study the genetic variation of beech in specific Carpathian regions and in regions from Romania defined as marginal for beech distribution (Ciocîrlan 2014, Ciocîrlan et al. 2017). Genetic studies in stands distributed over the whole continuous distribution zone of beech in the Romanian Carpathians are still missing.

According to Pârnuță et al. (2005, 2010) the actual regions of provenance in Romania were delineated based on previous forest seed harvesting zones (Enescu et al. 1988), ecological forest regions (Doniță et al. 1980) and the National Forest Map (Doniță et al. 1997). In the decision process results from progeny tests for the main forest tree species were also considered as well as forest site quality information. The defined regions of provenance were approved by Ministry Order No. 1028/2010 (Anonymous 2010).

The Romanian Act of Forest Reproductive Material (Anonymous 2011) regulates the production, marketing and control of forest reproductive material (FRM), and implements the requirements of the European Council Directive 1999/105/EC. Following this law seed for forestry purposes has to be collected in seed units (stands and seed orchards) introduced into the National Catalogue of Basic Material for Production of FRM (Anonymous 2012). 66 countries are selected mainly based on phenotypic criteria; genetic diversity is not considered at all, even if it is crucial for adaptation of future forests to changing environmental conditions (e.g. Konnert et al. 2015). In Southern Germany for the approval of seed stands for Silver fir beside phenotypic criteria the genetic diversity is also considered. Stands with low genetic diversity are not selected for seed collection (Cremer et al. 2014). For Douglas fir selection of seed stands in some regions in Germany the genetic composition and genetic diversity of the populations is crucial (Konnert et al. 2010). Delineation of seed zones generally is done based on ecological criteria. Rarely genetic aspects are also considered (Gömöry et al. 1998). Genetic analysis for beech seed stands refers at present only to the control of seed harvesting procedures (e.g. Janssen 2000) and assignment of seed to the mother tree within a traceability system (Hasenkamp et al. 2011).

In the present study nuclear microsatellites were used to determine the genetic variability in natural beech populations, registered as seed stands. The focus was on genetic diversity within populations and genetic differences between populations. The transmission of the genetic diversity to the next generation was assessed by comparing the adult stand with the natural regeneration.

\section{Materials and methods}

\section{Plant material}

The ten investigated seed stands are located in ten different provenance regions situated in different ecological sectors with high amount of beech forests; more information on single stands is given in Table 1. In each stand cambium from 25 to 51 adult trees was collected. In six selected stands (see Table 1) seedlings from 48 juveniles per stand were also sampled in 3 - 4 regeneration gaps located near the sampled adult trees. Altogether 724 individuals 
Table 1 Description of the investigated European beech (Fagus sylvatica) seed stands

\begin{tabular}{|c|c|c|c|c|c|c|c|}
\hline \multirow{2}{*}{$\begin{array}{l}\text { Population } \\
\text { name }\end{array}$} & \multirow{2}{*}{$\begin{array}{l}\text { Region of } \\
\text { provenance }\end{array}$} & \multicolumn{2}{|c|}{ Geographic coordinates } & \multirow{2}{*}{$\begin{array}{l}\text {-Age of } \\
\text { adult stand }\end{array}$} & \multirow{2}{*}{ Altitude } & \multicolumn{2}{|c|}{ No. of sampled trees } \\
\hline & & Latitude & Longitude & & & Adults & Seedlings \\
\hline Feldru & A120 & $47^{\circ} 30.440^{\circ}$ & $24^{\circ} 45.768^{\circ}$ & 90 & 1200 & 48 & 48 \\
\hline Sovata & $\mathrm{A} 130$ & $46^{\circ} 38.706^{\circ}$ & $25^{\circ} 07.818^{\circ}$ & 105 & 850 & 48 & 47 \\
\hline Dragomirna & G150 & $47^{\circ} 45^{\prime} 450^{\prime}$ & $26^{\circ} 14.370^{\circ}$ & 120 & 430 & 51 & - \\
\hline Fântânele & G340 & $46^{\circ} 38^{\circ} 279^{\prime}$ & $26^{\circ} 48.457^{\circ}$ & 95 & 360 & 25 & - \\
\hline Brașov & B130 & $45^{\circ} 30.291^{\prime}$ & $25^{\circ} 51.389^{\circ}$ & 130 & 1000 & 48 & 48 \\
\hline Băile Govora & $\mathrm{C} 240$ & $45^{\circ} 04^{\prime} 341^{\prime}$ & $24^{\circ} 10.235^{\circ}$ & 140 & 350 & 50 & - \\
\hline Sebeș & $\mathrm{C} 130$ & $45^{\circ} 48.191^{\circ}$ & $23^{\circ} 29.915^{\circ}$ & 145 & 800 & 48 & 48 \\
\hline Ciucea & E340 & $46^{\circ} 59.171^{\circ}$ & $22^{\circ} 55.467^{\circ}$ & 70 & 620 & 48 & 47 \\
\hline Bârzava & E140 & $46^{\circ} 09^{\prime} 133^{\circ}$ & $22^{\circ} 07.388^{\circ}$ & 110 & 400 & 24 & - \\
\hline Băile Herculan & D150 & $44^{\circ} 55.106^{6}$ & $22^{\circ} 26.650^{\circ}$ & 110 & 380 & 48 & 48 \\
\hline
\end{tabular}

Note. Abbreviations: A120 - Inner Eastern Carpathian, Mixed forest of European beech and coniferous, A130 Inner Eastern Carpathian, Mountain European beech forest, G150 - Suceava Plateau and Siret hills, Hilly mixed hardwood forest with Sessile oak, G340 - Bârlad Plateau and Bacău hills, Hilly European beech pure or mixed forests with other broadleaves species, B130 - Curvature Carpathians: Brașov Depression, Mountain European beech forest, C240 - Southern Carpathians: southern part, Hilly European beech pure or mixed forests with other broadleaves species, C130 - Southern Carpathians: northern part, Mountain European beech forest, E340 - Apuseni Mountains: eastern part, Hilly European beech pure or mixed forests with other broadleaves species, E140 - Apuseni Mountains: Zarand and Metaliferous Mts, Hilly European beech pure or mixed forests with other broadleaves species, D150 - Banat Mountains: Mehedinț-Cerna-Semenic Mts, Hilly mixed hardwood forest with Sessile oak.

were analyzed.

\section{DNA isolation}

For DNA isolation the modified ATMAP method (Dumolin et al. 1995) was applied. Before extraction, cambium was lyophilized for 20 hours in a freeze-dryer (Christ Alpha 1-2 LDplus) at $-55{ }^{\circ} \mathrm{C}$ and 0.021 mbar pressure. Buds ( 2 buds per tree) were lyophilized by storage on silica gel for one week. DNA concentration and purity were determined spectrophotometrically with the Gene Quant Pro, Amersham Bioscience followed by dilution of the DNA extracts to $20 \mathrm{ng} / \mu \mathrm{l}$.

\section{PCR amplification}

For PCR amplification the Qiagen-multiplex-Kit was used. All samples were analyzed with ten highly polymorphic nuclear microsatellites (Table 2) combined into two PCR systems. PCR multiplex A comprised primers mfc11 (Tanaka et al. 1999), FS3-04, FS1-15 (Pastorelli et al. 2003) and csolfagus19, csolfagus31 (Lefévre et al. 2012) while PCR multiplex B included mfs11 (Vornam et al. 2004), mfc5, mfc7 (Tanaka et al. 1999), sfc0036 (Asuka et al. 2004) and DE576A0 (Lefévre et al. 2012). Primers were labeled with the fluorescent dyes Dy751 (black), IRD700 (green) and Cy5 (blue). PCR amplifications were conducted in a solution of in total $15 \mu$ containing $1 \mu \mathrm{l}$ stock DNA, $7.5 \mu \mathrm{l}$ Qiagen Multiplex PCR Master Mix2x, $1.5 \mu$ Primer Mix, $3 \mu 1$ $\mathrm{H}_{2} \mathrm{O}$ RNase-free, $1 \mu \mathrm{l}$ PVP $1 \%$ and $1 \mu \mathrm{BSA}-$ Bovine Serum Albumin using a TProfessional Standard PCR Thermocycler Biometra, Germany. The following PCR protocol was applied: initial denaturation at $95^{\circ} \mathrm{C}$ for $15 \mathrm{~min}$, 28 cycles of $94^{\circ} \mathrm{C}$ for $30 \mathrm{sec}, 57^{\circ} \mathrm{C}$ for $90 \mathrm{sec}$, $72{ }^{\circ} \mathrm{C}$ for $30 \mathrm{sec}$ and a final elongation step at $60{ }^{\circ} \mathrm{C}$ for $30 \mathrm{~min}$.

Fragments were separated on the CEQ8000 (Beckman Coulter) automated fragment analyzer. $1 \mu \mathrm{l}$ of the multiplex PCR-amplifica- 
Table 2 Summary statistics for the 10 microsatellite loci

\begin{tabular}{lccccccc}
\hline Locus & Size range (bp) & No. of alleles & $\mathrm{N}_{\mathrm{A}}$ & $\mathrm{N}_{\mathrm{E}}$ & $\mathrm{H}_{\mathrm{O}}$ & $\mathrm{H}_{\mathrm{E}}$ & $\mathrm{F}$ \\
\hline csolfagus19 & $95-130$ & 16 & 11.3 & 4.880 & 0.806 & 0.789 & -0.022 \\
\hline csolfagus31 & $140-190$ & 17 & 10.8 & 6.078 & 0.834 & 0.831 & -0.004 \\
\hline FS3-04 & $187-200$ & 6 & 4.0 & 1.723 & 0.423 & 0.406 & -0.046 \\
\hline FS1-15 & $82-160$ & 27 & 12.5 & 6.614 & 0.841 & 0.843 & 0.003 \\
\hline mfc11 & $300-350$ & 15 & 8.4 & 2.987 & 0.545 & 0.645 & $0.158^{* * *}$ \\
\hline mfs11 & $100-170$ & 13 & 8.4 & 3.338 & 0.698 & 0.690 & -0.014 \\
\hline mfc5 & $260-350$ & 29 & 16.1 & 8.613 & 0.792 & 0.880 & $0.099 * * *$ \\
\hline mfc7 & $100-150$ & 17 & 7.3 & 1.733 & 0.421 & 0.407 & -0.032 \\
\hline sfc0036 & $90-125$ & 12 & 7.8 & 4.013 & 0.739 & 0.741 & 0.004 \\
\hline DE576A0 & $210-245$ & 8 & 5.3 & 3.093 & 0.685 & 0.668 & -0.026 \\
\hline \multirow{2}{*}{ Mean (overall) } & & 16 & 9.19 & 4.307 & 0.678 & 0.690 & 0.012 \\
& & & $( \pm 0.37)$ & $( \pm 0.182)$ & $( \pm 0.014)$ & $( \pm 0.014)$ & $( \pm 0.008)$ \\
\hline
\end{tabular}

Note. Abbreviations: $\mathrm{N}_{\mathrm{A}}$ - mean number of alleles per locus; $\mathrm{N}_{\mathrm{E}}$ - effective allele number; $\mathrm{H}_{\mathrm{O}}$ - observed heterozygosity; $\mathrm{H}_{\mathrm{E}}$ - expected heterozygosity; $\mathrm{F}$ - fixation index.

tion products, $30 \mu \mathrm{l}$ Sample Loading Solution (Beckmann Coulter) and $0.5 \mu \mathrm{l}$ Size Standard $\mathrm{CEQ}^{\mathrm{TM}}$ Kit 400 (Beckman Coulter) was mixed and applied on the capillary for electrophoretic separation. Allele assignment was carried out using the fragment analysis tool of GenomeLab $^{\mathrm{TM}}$ GeXP, interface of CEQ8000 Software.

\section{Data analysis}

To estimate the null allele frequencies per locus and per population the software MicroChecker 2.2.3 (Van Oosterhout et al. 2004) was used. For further calculation null allele frequencies were adjusted according to Van Oosterhout et al. (2004). This is necessary because the presence of null alleles can cause a bias in estimation of allele frequencies (Nascimento de Sousa et al. 2005), inbreeding coefficient (Chybicki \& Burczyk 2009), $\mathrm{F}_{\mathrm{ST}}$ and genetic distances (Chapuis \& Estoup 2007), parentage analysis (Dow \& Aschley 1998, Dakin \& Avise 2004, Oddou-Muratorio et al. 2009) and in Bayesian assignment testing (Falush et al. 2007, Carlsson 2008, Chapuis et al. 2008).

For population estimation of genetic diversity the following parameters were calculated using the program GenAlEx 6.502 (Peakall 68
\& Smouse 2012): mean number of alleles per locus $\left(\mathrm{N}_{\mathrm{A}}\right)$, mean number of private alleles within a population $\left(\mathrm{N}_{\mathrm{p}}\right)$, the effective number of alleles $\left(\mathrm{N}_{\mathrm{E}}\right)$ (Kimura \& Crow 1964), heterozygosity values $\left(\mathrm{H}_{\mathrm{O}}\right.$ and $\left.\mathrm{H}_{\mathrm{E}}\right)$ (Nei et al. 1975, Hamrick et al. 1992, Hartl \& Clark 1997), the fixation index $\mathrm{F}$ and the inbreeding coefficient $\mathrm{F}_{\text {IS }}$ (Hartl \& Clark 1997). Allelic richness (A) was calculated with the software FSTAT (Goudet 2002) based on a rarefaction method (Hurlbert 1971) to correct unequal sample size. It represents the mean number of alleles per locus (Leberg 2002).

Genetic differentiation among populations was estimated by Nei's (1972) pairwise genetic distance calculated with GenAlEx 6.502 (Peakall \& Smouse 2012) and by pairwise $\mathrm{F}_{\mathrm{ST}}$ (Weir \& Cockerham 1984) calculated with ARLEQUIN (Excoffier \& Lischer 2010). The pairwise $\mathrm{F}_{\mathrm{ST}}$ values at the 0.05 significance level were tested by 10.000 permutations. Using POPTREEW (Takezaki et al. 2014) a cluster analysis was performed based on Nei's standard genetic distance (Nei 1972) and a dendrogram was produced with the unweighted pair group mean arithmetic method (UPGMA). For statistical significance of the cluster nodes, bootstrapping was applied with 10.000 replications. 
Analysis of molecular variance (AMOVA) was performed in GenAlEx 6.502 (Peakall \& Smouse 2012) using 9.999 random permutations to estimate the distribution of total variance at different variation levels. A Mantel test (1967) was performed in the same programe with 9.999 permutations to estimate whether a statistically significant correlation exist between Nei's and $\mathrm{F}_{\mathrm{ST}}$ genetic distance matrix and the geographic distance matrix.

In addition a Bayesian approach implemented in the software STRUCTURE 2.3.4 (Pritchard et al. 2000, Falush et al. 2003) was used to detect the genetic differentiation of the ten beech populations. The admixture model and correlated allele frequencies were used with the following parameter set: 100.000 MCMC iterations after 100.000 burn-in periods. $\mathrm{K}$ was defined between $1-15$, with 20 iterations for each $\mathrm{K}$. Implementing ad hoc statistics $\Delta \mathrm{K}$ (Evanno et al. 2005) the uppermost hierarchical level was precisely detected among runs $K=1-15$. The best estimate of $K$ (number of estimated clusters) was calculated with the web-based STRUCTURE HARVESTER program (Earl \& von Holdt 2012).

\section{Results}

\section{Null alleles}

Null allele tendency was observed mainly at the loci mfc11 and mfc5. For mfc11 eight out of ten populations show such alleles, with frequencies $(r)$ varying from 0.060 (Feldru) to 0.206 (Braşov). At the locus mfc5 null alleles were observed in four populations, with the lowest frequency in Feldru (0.012) and the highest in Băile Govora (0.146). For the other loci null alleles were observed only in one population, as for example for mfs11 in Băile Govora $(r=0.109)$, for csolf19 in Bârzava $(r=$ $0.099)$ and for DE576A0 and FS1-15 in Sovata ( $r=0.099$ resp. $r=0.059$ ). The situation was similar in the natural regeneration, where null alleles occur mainly at the loci mfc11 (2 popu- lations) and $\mathrm{mfc} 5$ (3 populations).

\section{Genetic diversity}

All ten analyzed microsatellite loci were polymorphic with 6 (locus FS3-04) to 29 alleles (locus mfc5) per locus and a total of 160. Considering all adult populations and the natural regeneration together the highest mean number of alleles $\left(\mathrm{N}_{\mathrm{A}}=16.1\right)$ and the highest $\mathrm{N}_{\mathrm{E}}$ value $(=8.613)$ was detected for the primer mfc5. The observed heterozygosity $\left(\mathrm{H}_{\mathrm{O}}\right)$ varied between 0.421 (mfc7) and 0.841 (FS1-15) with a mean value of $0.678( \pm 0.014) . H_{E}$ has values between 0.406 (FS3-04) and 0.880 (mfc5) with a mean of $0.690( \pm 0.014)$. The fixation index $F$ was significantly different from zero only for the loci $\mathrm{mfc} 11$ and $\mathrm{mfc5}$. Even after adjustment of null alleles the deficit in heterozygote individuals for both loci remained significant.

At the population level parameter values are given in Table 3 . In adult stands the mean number of alleles per locus $\left(\mathrm{N}_{\mathrm{A}}\right)$ varied from 8.0 in Bârzava to 10.9 in Băile-Herculane, in the natural regeneration from 8.3 (Ciucea) to 9.6 (Sebes and Băile Herculane). In nine populations, between them adult stands and natural regeneration private alleles $\left(\mathrm{N}_{\mathrm{p}}\right)$ were found. The effective number of alleles $\left(\mathrm{N}_{\mathrm{E}}\right)$ varied in adult stands between 4.01 in Dragomirna and 5.43 in Băile Govora and for natural regeneration between 3.87 (Feldru) and 4.25 (Sovata). For adult stands the observed heterozygosity $\left(\mathrm{H}_{\mathrm{O}}\right)$ values ranged from 0.637 in Bârzava to 0.750 in Băile Govora with the mean of $0.681( \pm 0.018)$. In natural regeneration $\mathrm{H}_{\mathrm{O}}$ is lowest in Băile Herculane (0.651) and highest in Feldru (0.696). Between observed and expected heterozygosity $\left(\mathrm{H}_{\mathrm{E}}\right)$ differences are low and statistically not significant. Subsequently the inbreeding coefficient $\mathrm{F}_{\text {IS }}$ was generally close to zero, with a mean value of 0.014 $( \pm 0.010)$ in adult stands and $0.008( \pm 0.012)$ in natural regeneration.

\section{Genetic differentiation}


Table 3 Summary statistics for the 10 microsatellite loci

\begin{tabular}{|c|c|c|c|c|c|c|c|c|c|}
\hline No. & Population & & $\mathrm{N}_{\mathrm{A}}$ & $\mathrm{A}$ & $\mathrm{N}_{\mathrm{p}}$ & $\mathrm{N}_{\mathrm{E}}$ & $\mathrm{H}_{\mathrm{O}}$ & $\mathrm{H}_{\mathrm{E}}$ & $\mathrm{F}_{\text {IS }}$ \\
\hline \multirow{2}{*}{1} & \multirow{2}{*}{ Feldru } & Ad & 10.5 & 8.761 & 4 & 4.544 & 0.688 & 0.707 & 0.030 \\
\hline & & $\mathrm{S}$ & 8.5 & 7.309 & 3 & 3.870 & 0.696 & 0.679 & -0.032 \\
\hline \multirow{2}{*}{2} & \multirow{2}{*}{ Sovata } & $\mathrm{Ad}$ & 9.4 & 7.961 & 0 & 4.295 & 0.698 & 0.703 & -0.003 \\
\hline & & $\mathrm{s}$ & 9.0 & 7.779 & 1 & 4.258 & 0.685 & 0.691 & 0.003 \\
\hline 3 & Dragomirna & Ad & 8.7 & 7.655 & 0 & 4.010 & 0.645 & 0.676 & 0.048 \\
\hline 4 & Fântănele & Ad & 8.7 & 8.700 & 0 & 4,339 & 0.673 & 0.672 & -0.013 \\
\hline \multirow{2}{*}{5} & \multirow{2}{*}{ Braşov } & Ad & 9.5 & 7.990 & 0 & 4.089 & 0.669 & 0.682 & 0.008 \\
\hline & & $\mathrm{s}$ & 9.0 & 7.638 & 2 & 3.987 & 0.672 & 0.687 & 0.020 \\
\hline 6 & Băile Govora & Ad & 10.4 & 9.039 & 3 & 5.439 & 0.750 & 0.757 & 0.006 \\
\hline \multirow{2}{*}{7} & \multirow{2}{*}{ Sebeș } & $\mathrm{Ad}$ & 8.9 & 7.939 & 0 & 4.118 & 0.690 & 0.678 & -0.021 \\
\hline & & $\mathrm{s}$ & 9.6 & 8.364 & 1 & 4.156 & 0.658 & 0.703 & 0.061 \\
\hline \multirow{2}{*}{8} & \multirow{2}{*}{ Ciucea } & Ad & 8.9 & 7.705 & 0 & 4.377 & 0.660 & 0.691 & 0.035 \\
\hline & & $\mathrm{s}$ & 8.3 & 7.342 & 0 & 4.093 & 0.687 & 0.696 & 0.011 \\
\hline 9 & Bârzava & Ad & 8.0 & 8.000 & 1 & 4.226 & 0.637 & 0.657 & 0.039 \\
\hline \multirow{2}{*}{10} & \multirow{2}{*}{$\begin{array}{l}\text { Băile- } \\
\text { Herculane }\end{array}$} & Ad & 10.9 & 9.266 & 3 & 5.016 & 0.696 & 0.715 & 0.014 \\
\hline & & $\mathrm{s}$ & 9.6 & 8.349 & 3 & 4.098 & 0.651 & 0.648 & -0.013 \\
\hline
\end{tabular}

Note. Abbreviations: $\mathrm{N}_{\mathrm{A}}$ - mean number of alleles per locus; $\mathrm{N}_{\mathrm{E}}$ - effective allele number; $\mathrm{N}_{\mathrm{P}}-$ private allele number; $A$ - allelic richness, $\mathrm{H}_{\mathrm{O}}$ - observed heterozygosity; $\mathrm{H}_{\mathrm{E}}$ - expected heterozygosity; $\mathrm{F}_{\mathrm{IS}}$-inbreeding coefficient; Ad - adult stand, s - seedlings.

\section{Genetic differences between adult stands}

Between the adult stands genetic distance (Nei 1972) varied between 0.042 (Sovata to Dragomirna) and 0.088 (Feldru to Băile Herculane) (Table 4). Pairwise $\mathrm{F}_{\mathrm{ST}}$ values ranged from 0.004 (Braşov to Fântânele) to 0.023 (Feldru respectively Dragomirna to Băile-Herculane). The overall genetic differentiation $\mathrm{F}_{\mathrm{ST}}$ between populations averaged 0.014 .

Cluster analysis based on Nei's distance indicates a division in four distinct groups. This is visualized by the dendrogram in Figure 1a. The first group consists of four populations (Feldru, Sovata, Dragomirna and Ciucea) from Northern Romania. Another group contains two populations from the Central-West region (Sebeș and Bârzava), both populations situated along the Mureș river. The third group includes the populations from Fântânele and Braşov located in the Central-East region. The two southern populations Băile-Herculane and Băile Govora, clearly differentiated from the rest but cluster together at a higher genetic differentiation level.
Bayesian approach based on the allelic frequency of all nSSR markers (STRUCTURE analysis) didn't confirm the presence of four groups, detected earlier by cluster analysis. In this analysis the most likely number of clusters was three, $K=3$ (Figure 2a). Admixture of clusters indicates a week differentiation among the studied stands (Figure 3b). The two southern populations (Băile-Herculane and Băile Govora) contain in the highest percent the blue group and the red group, respectively, while in populations Bârzava and Sebeș the green group has the largest percentage. The rest of the populations show a mixture of these three clusters (Figure 3 ).

The Mantel test denoted a positive and statistically highly significant correlation between the geographic distance and Nei's genetic distance $(\mathrm{r}=0.553, \mathrm{P}=0.0002)$ as well as between geographic distance and $\mathrm{F}_{\mathrm{ST}}(\mathrm{r}=$ $0.579, \mathrm{P}=0.0001)$. This indicates that there is some differentiation by distance probably due to the natural barriers of the Transylvanian Plateau and the high peaks of the Carpathians.

Molecular Variance Analysis (AMOVA) in- 

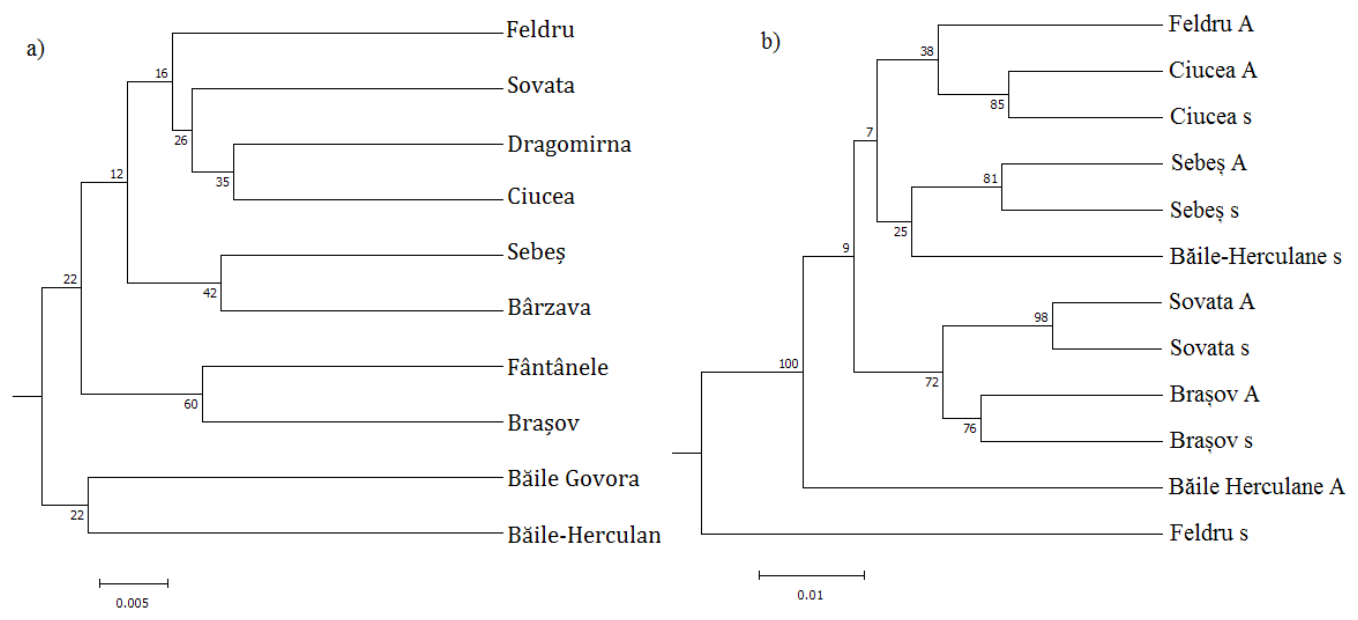

Figure 2 UPGMA dendrogram based on Nei's genetic distance with 10000 bootstraps: a) among 10 adult beech stands b) among 6 adult stands and their natural regeneration (A - adult; $\mathrm{s}$ - seedling)

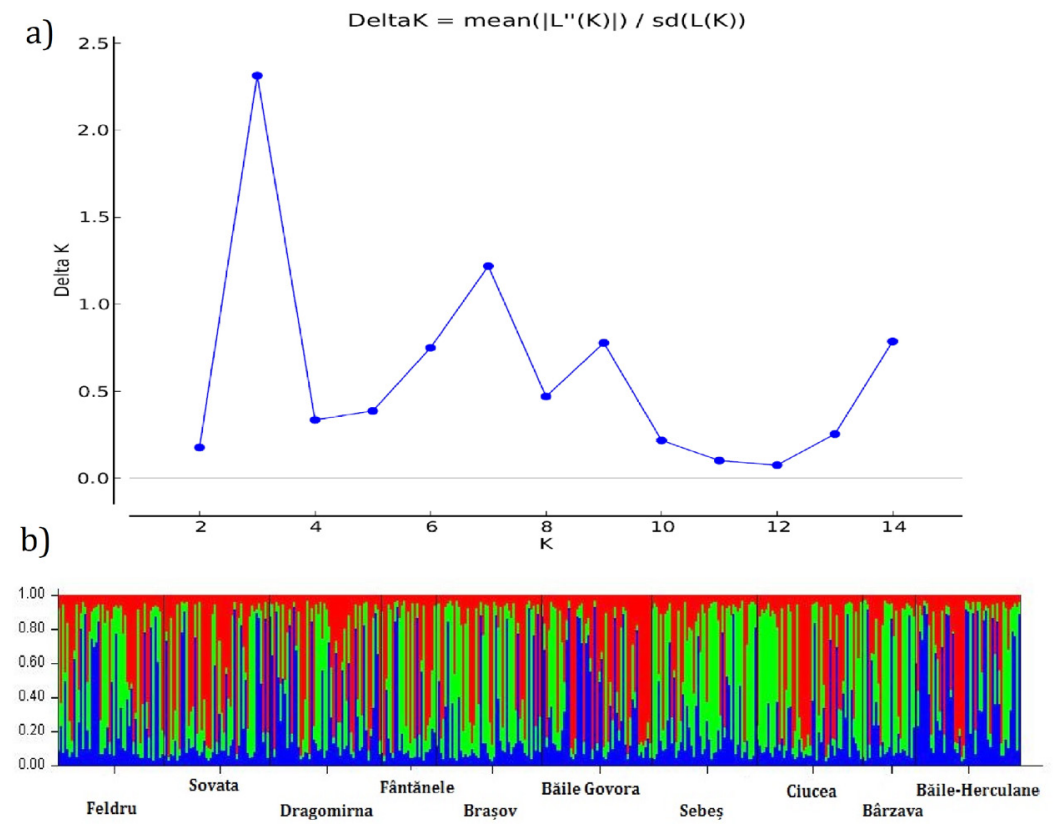

Figure 3 Results of STRUCUTURE analysis a) values for delta $\mathrm{K} \mathrm{b}$ ) membership proportion of the individuals to the three clusters

dicates that $96.22 \%$ of total variance is found within individuals, $2.36 \%$ among individuals within population and only $1.42 \%$ among populations (Table 5).

\section{Genetic differences between adult stands and regeneration}

Genetic distance (Nei 1972) between the adult 
Table 4 Nei's genetic distance matrix for the studied populations

\begin{tabular}{|c|c|c|c|c|c|c|c|c|c|c|c|c|c|}
\hline Pop & $\mathrm{Fe}$ & So & Dr & Fâ & $\mathrm{Br}$ & $\mathrm{BaG}$ & $\mathrm{Se}$ & $\mathrm{Ci}$ & Bâr & $\mathrm{BaH}$ & $\mathrm{FeS}$ & SoS $\mathrm{BrS}$ & SeS CiS \\
\hline $\mathrm{Fe}$ & 0.000 & & & & & & & & & & & & \\
\hline So & 0.045 & 0.000 & & & & & & & & & & & \\
\hline Dr & 0.055 & 0.042 & 0.000 & & & & & & & & & & \\
\hline Fâ & 0.078 & 0.058 & 0.058 & 0.000 & & & & & & & & & \\
\hline $\mathrm{Br}$ & 0.072 & 0.048 & 0.064 & 0.045 & 0.000 & & & & & & & & \\
\hline $\mathrm{BaG}$ & 0.075 & 0.054 & 0.053 & 0.077 & 0.057 & 0.000 & & & & & & & \\
\hline $\mathrm{Se}$ & 0.058 & 0.057 & 0.054 & 0.067 & 0.050 & 0.070 & 0.000 & & & & & & \\
\hline $\mathrm{Ci}$ & 0.044 & 0.048 & 0.039 & 0.069 & 0.059 & 0.056 & 0.048 & 0.000 & & & & & \\
\hline Bâr & 0.046 & 0.062 & 0.064 & 0.072 & 0.060 & 0.069 & 0.044 & 0.046 & 0.000 & & & & \\
\hline $\mathrm{BaH}$ & 0.088 & 0.084 & 0.079 & 0.083 & 0.057 & 0.060 & 0.069 & 0.057 & 0.047 & 0.000 & & & \\
\hline $\mathrm{FeS}$ & 0.046 & 0.075 & 0.104 & 0.111 & 0.100 & 0.110 & 0.090 & 0.082 & 0.079 & 0.109 & 0.000 & & \\
\hline SoS & 0.051 & 0.020 & 0.041 & 0.049 & 0.036 & 0.054 & 0.061 & 0.040 & 0.053 & 0.066 & 0.083 & 0.000 & \\
\hline $\mathrm{BrS}$ & 0.062 & 0.047 & 0.066 & 0.047 & 0.034 & 0.084 & 0.054 & 0.062 & 0.063 & 0.081 & 0.103 & 0.0340 .000 & \\
\hline $\mathrm{SeS}$ & 0.057 & 0.052 & 0.059 & 0.068 & 0.051 & 0.069 & 0.030 & 0.050 & 0.040 & 0.049 & 0.094 & 0.0540 .046 & 0.000 \\
\hline $\mathrm{CiS}$ & 0.042 & 0.051 & 0.050 & 0.073 & 0.070 & 0.084 & 0.041 & 0.030 & 0.058 & 0.083 & 0.074 & $\begin{array}{l}0.052 \quad 0.061 \\
\end{array}$ & 0.0450 .000 \\
\hline BaHS & 0.069 & 0.086 & 0.075 & 0.088 & 0.069 & 0.079 & 0.049 & 0.053 & 0.035 & 0.049 & 0.109 & 0.0680 .073 & 0.047 \\
\hline
\end{tabular}

Note. Abbreviation: in orange - adult stands distance matrix, in yellow - the highest and smallest genetic distance value between adult stands, in gray - the genetic distance values between adults and their natural regeneration; Samplings: Fe - Feldru, So - Sovata, Dr - Dragomirna, Fâ - Fântănele, Br - Braşov, BaG - Băile Govora, Se - Sebeș, Ci - Ciucea, Bâr - Bârzava, BaH - Băile Herculane, FeS - Feldru Seedlings, SoS - Sovata Seedlings, BrS - Braşov Seedlings, SeS - Sebeș Seedlings, CiS - Ciucea Seedlings, BaHS - Băile Herculane Seedlings.

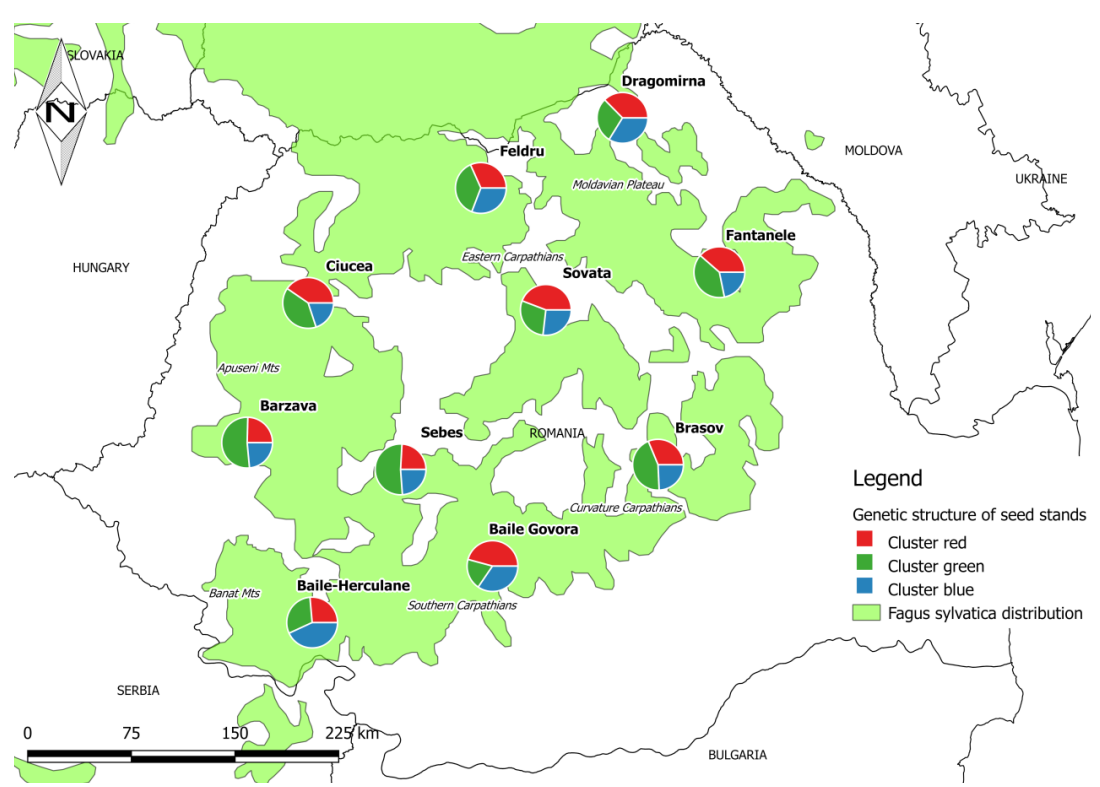

Figure 4 Genetic structure of seed stands detected by STRUCTURE analysis ( $F$. sylvatica distribution map source: EUFORGEN) 
Table 5 Results of hierarchical molecular variance analysis (AMOVA) for F. sylvatica adult stands

\begin{tabular}{|c|c|c|c|c|c|c|c|}
\hline Source of variation & Df & SS & MS & $\begin{array}{c}\text { Estimated } \\
\text { variation }\end{array}$ & $\begin{array}{c}\text { Percentage } \\
\text { variation }(\%)\end{array}$ & F-statistics & P-value \\
\hline Among populations & 9 & 72.66 & 8.07 & 0.05 & $1.42 \%$ & $\mathrm{~F}_{\mathrm{st}}=0.014$ & \multirow{4}{*}{$<0.001$} \\
\hline $\begin{array}{l}\text { Among individuals } \\
\text { within populations }\end{array}$ & 428 & 1553.67 & 3.63 & 0.08 & $2.36 \%$ & $\mathrm{~F}_{\mathrm{is}}=0.024$ & \\
\hline Within individuals & 438 & 1515.50 & 3.46 & 3.46 & $96.22 \%$ & $\mathrm{~F}_{\mathrm{it}}=0.038$ & \\
\hline Total & 875 & 3256.384 & & 3.59 & $100 \%$ & & \\
\hline
\end{tabular}

Note. Abbreviations: $D f$ - degree of freedom; $S S$ - sum of squares; $M S$ - mean sum of squares; $P$ - probability.

stands and their natural regeneration varied between 0.020 (Sovata) and 0.049 (Băile Herculane) (Table 4). $\mathrm{F}_{\mathrm{ST}}$ pairwise values ranged from 0.004 (Sovata) to 0.013 (Băile Herculane). The genetic distance between adults and natural regeneration is somewhat higher in the populations Feldru (0.046) and Băile Herculane (0.049).

In general cluster analysis based on Nei's distance indicates that adult population and natural regeneration from the same population group together (Figure 1b) with the exception of the populations Feldru and Băile Herculane. Natural regeneration from Feldru groups completely apart, while natural regeneration from Băile-Herculane groups together with the other populations.

Similar results were obtained by the PCoA analysis. Here the first two principal coordinates explain almost half percent of the total genetic variance and confirm the small genetic distance between adults and natural regeneration (Figure 5).

\section{Discussion}

Our investigations revealed high genetic variation within and low genetic differentiation between the analyzed beech populations. This general genetic pattern was similar for European beech in almost all European regions as demonstrated mainly by isozyme studies (see Comps et al. 1990, Gömöry et al. 1992, Hazler et al. 1997, Konnert 1995, Leonardi \& Menozzi 1995, Merzeau et al. 1994). For
nSSR markers only few studies on genetic variability of beech populations exist (see Vornam et al. 2004, Buiteveld et al. 2007, Ciocîrlan 2014, Ciocîrlan et al. 2017, Lander et al. 2011, Liesebach et al. 2015, Kempf \& Konnert 2016). Szasz-Len (2016) conducted a PCoA and STRUCTURE analysis with the presented 10 populations from Romania and 16 European beech populations from Germany and Bulgaria. In this study beech stands from Romania group together with stands from Bulgaria and are clearly differentiated from German stands. This leads to the conclusion that Bulgarian and Romanian beech population share a common gene pool which is clearly different from the gene pool of stands in Germany. Based on this result for beech the existence of two main genetic groups, one from South-Eastern Europe and another from Central Europe is assumed.

These results are conflictive to the findings of Magri et al. (2006), who postulated the complete isolation of Balkan beech populations from the Romanian ones and support the assumption of Gömöry et al. (2003) that Carpathian and Balkan beech populations have a common post-glacial origin. The same authors assumed a glacial refugium in the Southern Carpathians or adjacent regions. Although pollen data analysis certified the diffuse presence of Fagus already from the beginning of the Holocene in the Romanian Carpathians (c. 8500-7500 years ago) (Feurdean 2005, Tanţău et al. 2006, 2009, 2011) there is no clear evidence that beech populations had survived and expanded from a Carpathian refugium.

In general the genetic diversity and hetero- 


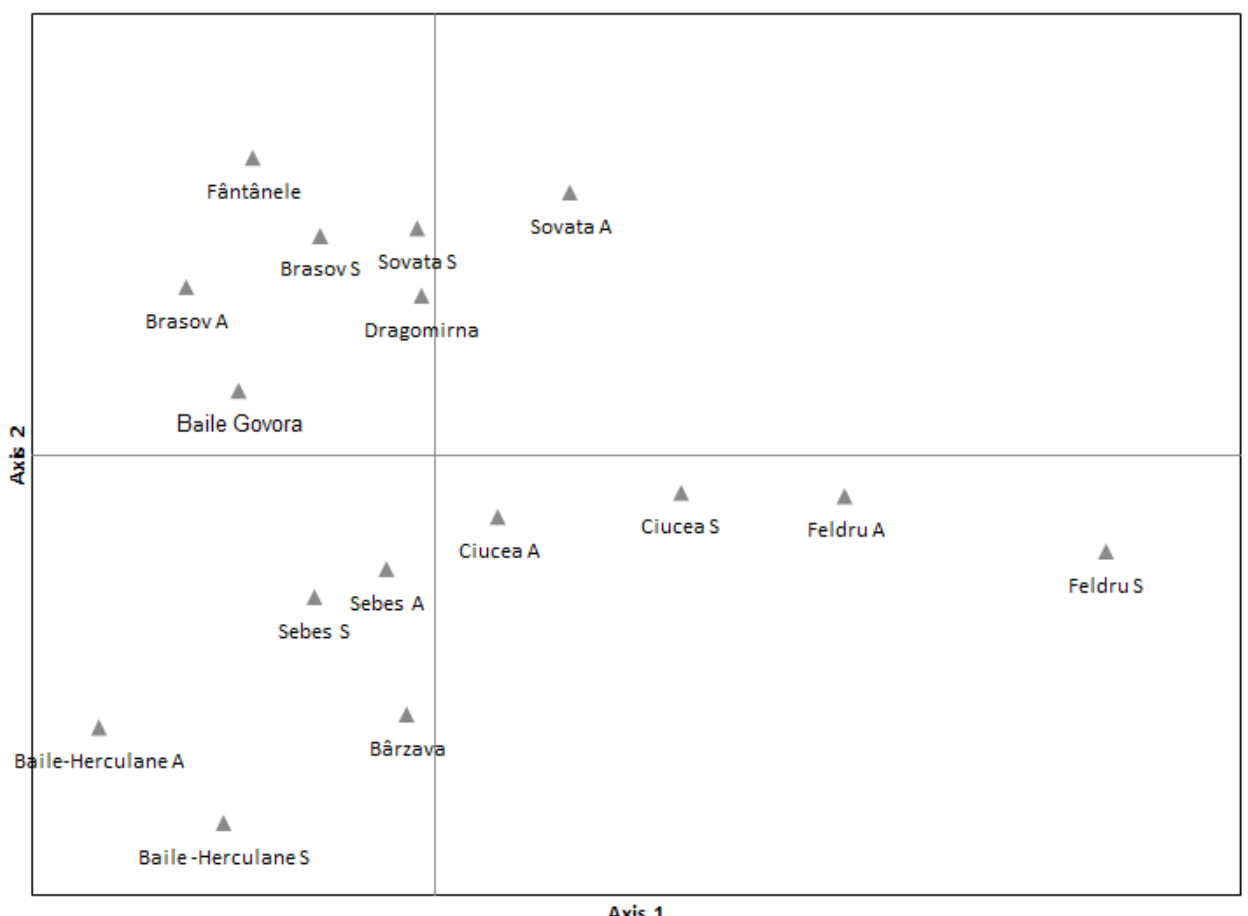

Figure 5 Principale Coordinates Analysis (PCoA) for the studied populations based on Nei's genetic distance (1972) - adult trees (A), natural regeneration (S)

zygosity of the investigated populations was related to populations of Fagus sylvatica from Central Europe (Vornam et al. 2004, Dounavi et al. 2016, Kempf \& Konnert 2016), even if partially different markers were used and a direct comparison of results is difficult. Thus for example for 13 beech populations in the marginal and core areas of beech distribution in Romania Ciocîrlan (2014) based on eight nuclear microsatellites calculated a mean observed heterozygosity of 0.651 , whereas the overall expected heterozygosity was 0.703 . Liesebach et al. (2015), using 14 nSSR primers, reported slightly higher heterozygosity values with $\mathrm{H}_{\mathrm{O}}=0.656$ and $\mathrm{H}_{\mathrm{E}}=0.729$ for the provenance Beiuş (Bihor) included in an international field trial.

In the ten investigated populations values for observed and expected heterozygosities were nearly similar. In conclusion $\mathrm{F}_{\text {IS }}$ values are nearby zero and populations can be considered 74 to be in Hardy-Weinberg equilibrium (Hartl \& Clark 1997). This holds also for natural regeneration, where inbreeding effects can be excluded. The $\mathrm{F}_{\text {IS }}$ value were lower compared to other populations from Central Europe $\left(\mathrm{F}_{\mathrm{IS}}=0.224\right.$, Buiteveld et al. 2007) and from Italy $\left(\mathrm{F}_{\mathrm{IS}}=0.238-0.241\right.$, Paffetti et al. 2012) and similar to $\mathrm{F}_{\mathrm{IS}}$ values found in populations from Germany $\left(\mathrm{F}_{\mathrm{IS}}=-0.002-0.0015\right.$, Rajendra et al. 2014), France $\left(F_{I S}=-0.044\right.$, Lefévre et al. 2012, $\mathrm{F}_{\text {IS }}=-0.013$, De Lafontaine et al. 2013) and parts of Poland $\left(F_{I S}=0.004\right.$, Kempf $\&$ Konnert 2016). In northeastern Spain $\left(\mathrm{F}_{\text {IS }}=\right.$ 0.088, Jump \& Penuelas, 2007) and some other Polish populations $\left(\mathrm{F}_{\mathrm{IS}}=0.061\right.$, Sulkowska et al. 2012) as well as in marginal beech populations from Romania $\left(\mathrm{F}_{\mathrm{IS}}=0.064\right.$, Ciocîrlan 2014) slightly higher $F_{\text {IS }}$ values were observed. It is obvious that the values for the inbreeding coefficient depend to some extent also on the analyzed loci. If at a locus null alleles in high- 
er frequencies appear, the $\mathrm{F}_{\text {IS }}$ values increase (Buiteveld et al. 2007, Rajendra et al. 2014). In our study for loci $\mathrm{mfc5}$ and mfc11 significant amounts of null alleles were observed. Subsequentelly the $\mathrm{F}_{\mathrm{IS}}$ - values for these loci differ significantly from zero. The reason could be that the affected primers originally were designed for Fagus crenata (Tanaka et al. 1999) and then applied for Fagus sylvatica. Transferring primers to a closely related species frequently displays null alleles (Oddou-Muratorio et al. 2009).

The analyzed stands are declared as seed stands according to the Romanian Act of Forest Reproductive Material (Anonymous 3 2011) and are introduced into the National Catalogue of Basic Material for Production of FRM (Anonymous 4 2012). In such stands seed harvesting for artificial regeneration of stands is allowed. Especially under climate change planting material must be genetically diverse to assure that the new population can adapt and survive under changing conditions. This means that seed material with high genetic diversity is needed. The most important factors which influence the genetic composition and diversity of seed populations are the seed stand and the harvesting procedures (Hosius et al. 2006, Konnert 2010). The genetic composition of the seed stand is very important for the genetic composition of the seed. During generative propagation the gene pool of the adult tree population is transmitted in great part to the seed generation. Comparison with the other European regions shows that in the investigated stands from the Romanian Carpathians genetic diversity is not lower than in other European regions and somewhat higher than in marginal populations from Romania. At the same time all stands show nearly similar values. In conclusion from a genetic point of view the registration as seed stands can be supported. Collection of seed has to be done over the whole stand area. Studies for beech demonstrated that this procedure increases the genetic diversity in seed populations (Janssen
2000, Ziehe et al. 2004).

Most of the genetic diversity was determined within the stands. Differentiation between stands was very low (1.4\%). For beech populations from Poland Kempf \& Konnert (2016) reported a significant differentiation of $5 \%$ between stands and a significant geographic division between populations from Northern and Southern Poland. In the present study a clear geographic grouping was not observed. Most pronounced is the differentiation of the two southernmost populations Băile Herculane and Băile Govora. In general a homogenous beech gene pool within the Carpathian region can be assumed. Based on the neutral SSR markers analyzed a distinct geographical distribution of genetic diversity within Romanian Carpathians regions of provenance could not be detected. These results would allow the conclusion that larger provenance regions could be delineated for beech in the Carpathian regions. We do not know whether adaptive traits or putative adaptive markers such as isozymes show a lower spatial differentiation for beech in the analyzed region. However in an isozyme gene marker study on beech from the Czech Republic no small-scaled genetic differentiation was detected at all (Gömöry et al. 1998). It seems that for beech the genetically homogeneous regions are large (Cuguen et al. 1985, Müller-Starck \& Starke 1993, Gömöry et al. 1998) and the delineation of larger provenance regions would therefore be justified.

Natural regeneration has a great potential for retaining the gene pool over generations. In seed stands comparison of genetic diversity between generations is important as an indicator for gene flow and for the transmission of genetic information to the next generation. An undisturbed gene flow is very important for maintaining genetic diversity in the seed generation (Burczyk et al. 2004). Comparison of the investigated adult stands with their natural regeneration shows only slight and statistically not significant differences in allelic richness, genetic diversity and heterozygosity with no 
clear tendency for all stands. Thus we can conclude that regenerating these stands naturally has not implied a reduction in the genetic variation in the following generation. Genetic studies on this topic are rare in Central Europe and were carried out mainly in Germany (Starke 1996, Behm \& Konnert 1999, Tröber \& Brandes 2004, Ißleib \& Krabel 2005). All studies were based on isozymes and show only relatively small differences in genetic diversity between adults and their natural regeneration. No reduction in genetic variation of the natural regeneration is observed as long as stands are large enough and the number of trees participating in reproduction is high. The transmission of genetic variation to the next generation is strongly influenced by the stand management. To maintain the genetic diversity over generations it is important that the tree cutting intensity is low and trees are removed from different parts of the stand (Behm \& Konnert 1999, Konnert 2010). Therefore we recommend for beech seed stands in Romania a slow regeneration in small patches as given in the shelterwood silvicultural system. Studies in Italy, Austria and Germany show clearly that this management system allows an unrestricted gene flow and the preservation of genetic diversity over time (Hosius et al. 2006, Buiteveld et al. 2007, Konnert \& Hosius 2010, Rajendra et al. 2014, Kavaliauskas et al. 2018). Clear cuttings or even intensive cuttings with strong reduction of the effective population size can cause the loss of rare alleles over time and a reduction of genetic variability as demonstrated for example by Paffetti et al. (2012), who compared an old-growth unmanaged beech stand and a naturally regenerated beech stand after intensive harvesting.

In conclusion the present study improves the existing knowledge on the genetic pattern of beech in Romania and gives indication on the genetic quality, in terms of genetic diversity and adaptation to the local conditions and management procedure for selected seed stands.

\section{Acknowledgements}

The first author gratefully acknowledges the 11 month financial support for the Exchange scholarship program (MOE) of the German Federal Environmental Foundation (DBU) and for the one month financial support for the European Union Seventh Framework Programme FP7 under grant agreement no. 284181 ,Trees4Future" as well as use of the services and facilities of the Bavarian Office for Forest Seeding and Planting in Teisendorf. We are grateful to Dr Maria Teodosiu for the help in material collection in two beech seed stands.

\section{References}

Anonymous, 2016. Statistica activităților din silvicultură în anul 2015 [Statistics of Forestry Activities in 2015]. National Institute of Statistics, București.

Anonymous, 2010. Ordin nr. 1028 din 30/06/2010 privind aprobarea delimitării şi descrierii regiunilor de provenienţă pentru materialele de bază din care se obţin materiale forestiere de reproducere din categoriile "sursă identificată" şi "selecţionat", pentru speciile de interes forestier din România [Order no. 1028 of 30/06/2010 approving delimitation and description of regions of provenance for base materials from which is obtained forest reproductive material of "source identified" and "selected" categories for forest species of interest in Romania]. Official Journal no. 617 of 01 September 2010.

Anonymous, 2011. Legea nr. 107/2011 privind comercializarea materialelor forestiere de reproducere. [Law no. $107 / 2011$ on the marketing of forest reproductive material]. Monitorul Oficial no. 430 of 20 June 2011.

Anonymous, 2012. Catalogul Naţional al Materialelor de bază pentru producerea materialelor Forestiere de Reproducere [National Catalogue of Basic Materials for Production of Forest Reproductive Materials]. Edited by Ministry of Environment and Forestry, National Forest Administration - ROMSILVA and Institute of Forest Research and Management - ICAS, Editura Silvica, București.

Asuka Y., Tani N., Tsumura Y., Tomaru N., 2004. Development and characterization of microsatellite markers for Fagus crenata Blume. Molecular Ecology Notes 4: 101-103.

Behm A., Konnert M., 1999. Erhaltung forstlicher Genressourcen durch naturnahe Forstwirtschaft - eine reelle Chance? [Conservation of forest genetic resources through close to nature forestry - a real opportunity?] Mitteilungen der Bundesforschungsanstalt für Forstund Holzwirtschaft . Hamburg 194: 215-235. 
Buiteveld J., Vendramin G.G., Leonardi S., Kamer K., Geburek T., 2007. Genetic diversity and differentiation in European beech (Fagus sylvatica L.) stands varying in management history. Forest Ecology and Management 247(1-3): 98-106.

Burczyk J., DiFazio S.P., Adams, W.T., 2004. Gene flow in forest trees: how far do genes really travel?. Forest Genetics, 11(3/4): 179-192.

Carlsson J., 2008. Effects of microsatellite null alleles on assignment testing. Journal of Heredity. 99(6): 616-623.

Chapuis M.P., Estoup A., 2007. Microsatellite null alleles and estimation of population differentiation. Mol. Biol. Evol. 24(3): 621-631.

Chapuis M.P., Lecoq M., Michalakis Y., Loiseau A., Sword G.A., Piry S., Estoup A., 2008. Do outbreaks affect genetic population structure? A worldwide survey in Locusta migratoria, a pest plagued by microsatellite null alleles. Molecular ecology, 17(16): 3640-3653.

Chybicki I.J., Burczyk J., 2009. Simultaneous estimation of null alleles and inbreeding coefficients, Journal of Heredity 100: 106-113.

Ciocîrlan E., 2014. Structura genetică în populații marginale de fag (Fagus sylvatica L.) din România - evaluări cu markeri moleculari [Genetic structure of marginal beech (Fagus sylvatica L.) populations in Romania evaluations using molecular markers], $\mathrm{PhD}$ Thesis. Forestry Department. University Transilvania, Brașov.

Ciocîrlan E., Sofletea N., Ducci F., Curtu A.L., 2017. Patterns of genetic diversity in European beech (Fagus sylvatica L.) at the eastern margins of its distribution range. iForest-Biogeosciences and Forestry, 10(6): 916922.

Comps B., Gömöry D., Letouzey J., Thiébaut B., Petit R.J., 2001. Diverging trends between heterozygosity and allelic richness during postglacial colonization in the European beech. Genetics 157(1): 389-397.

Comps B., Thiébaut B., Paule L., Merzeau D., Letouzey, J., 1990. Allozymic variability in beechwoods (Fagus sylvatica L.) over central Europe: spatial differentiation among and within populations. Heredity 65: 407-417.

Cremer E., Fussi B., Konnert M. 2014. Forstgenetische Untersuchungen für die Praxis am ASP [Genetic investigations for forest practice at the ASP]. AFZ/Der Wald 16: 20-23.

Cuguen J., Thiébaut B., Ntsiba F., Barrière G., 1985. Enzymatic variability of beech stands (Fagus sylvatica L.) on three scales in Europe: evolutionary mechanisms, in: Jacquard P. (Ed.) Genetic Differentiation and Dispersal in Plants, NATO ASI Series, vol. G5, pp. 17-39.

Dakin E.E., Avise J.C., 2004. Microsatellite null alleles in parentage analysis. Heredity, 93(5): 504-509.

De Lafontaine G., Ducousso A., Lefèvre S., Magnanou E., Petit R.J., 2013. Stronger spatial genetic structure in recolonized areas than in refugia in the European beech. Molecular Ecology 22(17): 4397-4412.

Doniță N., Bândiu C., Biriș I., Stan D., Zolotovici GH., 1997. Harta forestieră a României [Romanian Forest Map]. RNP- ICAS Bucuresti.
Doniţă N., Chiriță C.D., Stănescu, V. et al., 1980. Zonarea şi regionarea ecologică a pădurilor din R.S. România [Ecological forest zones of R.S. Romania]. ICAS Seria a II a, Redacţia de propagandă tehnică agricolă. Bucureşti, p. 83.

Dounavi A., Netzer F., Celepirovic N., Ivanković M., Burger J., Figueroa A.G., Schön S., Simon J., Cremer E., Fussi B., Konnert M., Rennenberg H., 2016. Genetic and physiological differences of European beech provenances (F. sylvatica L.) exposed to drought stress. Forest Ecology and Management, 361: 226-236.

Dow B.D., Ashley M.V., 1998. High levels of gene flow in bur oak revealed by paternity analysis using microsatellites. Journal of Heredity, 89(1): 62-70.

Dumolin S., Demesure B., Petit R.J., 1995. Inheritance of chloroplast and mitochondrial genomes in pedunculated oak investigated with an efficient PCR method. Theoretical and Applied Genetic 91: 1253-1256.

Earl D.A., von Holdt B.M., 2012. STRUCTURE HARVESTER: a website and program for visualizing STRUCTURE output and implementing the Evanno method. Conservation Genetics Resources 4: 359-361.

Enescu V., Doniţă N., Bândiu C., Contescu L., Chiriță C.D., Roşu C., 1988. Zonele de recoltare a seminţelor forestiere din R.S. România [Forest seed harvesting zones of R.S. Romania], Min. Silviculturii, ICAS Seria a II a, Bucuresti, p. 60.

Evanno G., Regnaut S., Goudet J., 2005. Detecting the number of clusters of individuals using the software STRUCTURE: a simulation study. Molecular ecology 14: 2611-2620.

Excoffier L., Lischer H.E.L., 2010. Arlequin suite ver 3.5: A new series of programs to perform population genetics analyses under Linux and Windows. Molecular Ecology Resources 10: 564-567.

Falush D., Stephens M., Pritchard J.K., 2003. Inference of population structure using multilocus genotype data: linked loci and correlated allele frequencies. Genetics 164(4): 1567-1587.

Falush D., Stephens M., Pritchard J.K., 2007. Inference of population structure using multilocus genotype data: dominant markers and null alleles. Molecular Ecology Notes 7(4): 574-578.

Feurdean A., 2005. Holocene forest dynamics in northwestern Romania. The Holocene 15(3): 435-446.

Gömöry D., Hynek V., Paule L., 1998. Delineation of seed zones for European beech (Fagus sylvatica L.) in the Czech Republic based on isozyme gene markers. In Annales des Sciences Forestières 55(4): 425-436.

Gömöry D., Longauer R., Paule L., Krajmerová D., Schmidtová J., 2010. Across-species patterns of genetic variation in forest trees of Central Europe. Biodiversity and Conservation 19(7): 2025-2038.

Gömöry D., Paule L., Brus R., Zhelev P., Tomovic Z., Gracan J., 1999. Genetic differentiation and phylogeny of beech on the Balkan Peninsula. Jourbal of Evolutive Biology 12: 746-754.

Gömöry D., Paule L., Shvadchak I.M., Popescu F., Sul- 
kowska M., Hynek V., Longauer R., 2003. Spatial patterns of the genetic differentiation in European beech (Fagus sylvatica L.) at allozyme loci in the Carpathians and the adjacent regions. Silvae Genetica 52(2): 78-83.

Gömöry D., Vysny J., Comps B., Thiebaut B., 1992. Geographical patterns of genetic differentiation and diversity in European beech (Fagus sylvatica L.) populations in France. Biologia (Bratislava) 47: 571-579.

Goudet J., 2002. FSTAT: a computer program to calculate Fstatistics. Version 2.9.3.2. J Heredity 86: 485-486.

Hamrick J.L., Godt M.J.W., Sherman-Broyles S.L., 1992. Factors influencing levels of genetic diversity in woody plant species. New Forests 6: 95-124.

Hartl D.L., Clark A.G., 1997. Principles of Population Genetics 3rd Ed. Sunderland, Massachusetts: Sinauer Associates, Inc.

Hasenkamp N., Ziegenhagen B., Mengel C., Schulze L., Schmitt H.P., Liepelt S., 2011. Towards a DNA marker assisted seed source identification: a pilot study in European beech (Fagus sylvatica L.). European Journal of Forest Research 130(4): 513-519.

Hazler K., Comps B., Sugar I., Melovski L., Tashev A., Gracan J., 1997. Genetic structure of Fagus sylvatica L. populations in southeastern Europe. Silvae Genetica 46(4): 229-235.

Hosius B., Leinemann L., Konnert M., Bergmann F., 2006. Genetic aspects of forestry in the Central Europe. European Journal of Forest Research 125(4): 407-417.

Hurlbert S. H., 1971. The nonconcept of species diversity: a critique and alternative parameters. Ecology 52: 577-586.

Ißleib D., Krabel D., 2005. Untersuchungen genetischer Strukturen in Buchen-Beständen (Fagus sylvatica L.) des mittleren Erzgebirges. Teil 1: Isoenzym-Genmarker [Investigations of the genetic structure in beech stands (Fagus sylvatica L.) of the middle Ore Mountains. Part 1: Isoenzyme Gene Marker]. Forst und Holz 60:190193.

Janssen A., 2000. Untersuchungen zur genetischen Variation der Buche in Hessen: der Einfluss von Ernteverfahren auf die genetische Struktur von Saatgut eines Buchenbestandes [Studies on the genetic variation of beech in Hessen: the influence of harvesting methods on the genetic structure of seeds of a beech stand]. Forschungsberichte der Hessischen Landesanstalt für Forsteinrichtung, Waldforschung und Waldökologie 27: 142.

Jump A.S., Penuelas J., 2007. Extensive spatial genetic structure revealed by AFLP but not SSR molecular markers in the wind-pollinated tree, Fagus sylvatica. Molecular Ecology 16: 925-936.

Kavaliauskas D., Fussi B., Westergren M., Aravanopoulos F., Finzgar D., Baier R., Alizoti P., Bozic G., Avramidou E., Konnert M., Kraigher H., 2018. The Interplay between Forest Management Practices, Genetic Monitoring, and Other Long-Term Monitoring Systems. Forests 9(3): 133.

Kempf M., Konnert M., 2016. Distribution of genetic di- versity in Fagus sylvatica at the north-eastern edge of the natural range. Silva Fennica 50(4): article id 1663. DOI: $10.14214 /$ sf.1663.

Kim Z.S., 1985. Viability selection at an allozyme locus during development in European Beech (Fagus sylvatica L.). Silvae Genetica 34(4-5): 181-186.

Kimura M., Crow J.F., 1964. The number of alleles that can be maintained in a finite population. Genetics 49: 725-738

Konnert M., 1995. Investigations on the genetic variation of beech (Fagus sylvatica L.) in Bavaria. Silvae Genetica 44(5): 346-350.

Konnert M., 2010. Contribution of forest genetics for a sustainable forest management. Polska Akademia Umiejetnosci Prace Komisji Nauk Rolniczych, Lesnych I Weterynaryjnych Pau Nr. 13: 67-78.

Konnert M., Fady B., Gömöry D., A’hara S., Wolter F., Ducci F., Koskela J., Bozzano M., Maaten T., Kowalczyk J., 2015. Use and transfer of forest reproductive material in Europe in the context of climate change, European Forest Genetic Resources Programme (EUFORGEN), Bioversity International xvi, Rome, Italy, p.75.

Konnert M., Hosius B., 2010. Contribution of forest genetics for a sustainable forest management. Forstarchiv 81(4): 170-174.

Konnert M., Ruetz W., 2001. Genetic variation of beech (Fagus sylvatica L.) provenances in an international beech provenance trial. Forest Genetics 8(3): 173-184.

Konnert M., Zanker Th., Böhm H., 2010. Die Douglasie im bayerischen Staatswald [Douglas-fir in the Bavarian State forest]. AFZ/Der Wald 10, 26-28.

Lander T.A., Oddou-Muratorio S., Prouillet-Leplat H., Klein E.K., 2011. Reconstruction of a beech population bottleneck using archival demographic information and Bayesian analysis of genetic data. Molecular Ecology 20: 5182-5196.

Leberg P.L., 2002. Estimating allelic richness: Effects of sample size and bottlenecks. Molecular Ecology 11: 2445-2449.

Lefévre S., Wagner S., Petit R.J., de Lafontaine G., 2012. Multiplexed microsatellite markers for genetic studies of beech. Molecular Ecology Resources 12(3): 484491.

Leonardi S., Menozzi P., 1995. Genetic variability of $\mathrm{Fa}$ gus sylvatica L. in Italy: the role of postglacial recolonization. Journal of Heredity 75: 35-44.

Liesebach H., 2012. Genotypisierung mit nuklearen Mikrosatellitenmarkern - Möglichkeiten der Datenauswertung am Beispiel von Buchenpopulationen (Fagus sylvatica L.) aus einem Herkunftsversuch [Genetic characterisation of beech populations (Fagus sylvatica L.) from a provenance trial with nuclear microsatellite markers]. Landbauforsch 62(4): 221-236.

Liesebach H., Eusmann P., Liesebach M., 2015. Verwandtschaftsbeziehungen innerhalb von Prüfgliedern in Herkunftsversuchen - Beispiel Buche (Fagus sylvatica L.) [Sibship structure in samples from a provenance trial A case study in beech (Fagus sylvatica L.)]. Forstarchiv 
86(6): 174-182.

Longauer R., Gömöry D., Paule L., Blada I., Popescu F., Mankovska B., Müller-Stark G., Schubert R., Percy K., Szaro R.C., Karnosky D.F., 2004. Genetic effects of air pollution on forest tree species of the Carpathian Mountains. Environmental Pollution 130: 85 - 92.

Longauer R., Gömöry D., Paule L., Karnosky D.F., Mankovska B., Müller-Stark G., Percy K., Szaro R., 2001. Selection effects of air pollution on gene pools of Norway spruce, European silver fir and European beech. Environmental Pollution 115: 405-411.

Magri D, Vendramin G.G., Comps B., Dupanloup I., Geburek T., Gömöry D., Latałowa M., Litt T., Paule L., Roure J.M., Tantau I., van der Knaap W.O., Petit R.J., de Beaulieu J.-L., 2006. A new scenario for the Quaternary history of European beech populations: palaeobotanical evidence and genetic consequences. New Phytologist 171: 199-221.

Mantel N., 1967. The detection of disease clustering and a generalized regression approach. Cancer Research 27: 209-220

Merzeau D., Comps B., Thiebaut B., Cuguen J., Letouzey J., 1994. Genetic structure of natural stands of Fagus sylvatica L. (beech). Heredity 72: 269-277.

Milescu I., Alexe A., Nicovescu H., Suciu P., 1967. Fagul [The European beech]. Editura Agro-Silvică. Bucureşti, p. 244.

Müller-Starck G., Starke R., 1993. Inheritance of isoenzymes in European beech (Fagus sylvatica L.), Journal of Heredity 84: 291-296.

Nascimento de Sousa S., Finkeldey R., Gailing, O., 2005. Experimental verification of microsatellite null alleles in Norway spruce (Picea abies [L.] Karst.): Implications for population genetic studies. Plant Molecular Biology Reporter 23(2): 113-119.

Nei M, Maruyama T, Chakraborty R (1975) Bottleneck effect and genetic variability in populations. Evolution, 29: 1-10.

Nei M., 1972. Genetic distance between populations. American Naturalist 106: 283-392.

Oddou-Muratorio S., Vendramin G.G., Buiteveld J., Fady B., 2009. Population estimators or progeny tests: what is the best method to assess null allele frequencies at SSR loci? Conservation Genetics 10(5): 1343-1347

Paffetti D., Travaglini D., Buonamici A., Nocentini S., Vendramin G.G., Giannini R., Vettori C., 2012. The influence of forest management on beech (Fagus sylvatica L.) stand structure and genetic diversity. Forest Ecology and Management 284: 34-44.

Pârnuţă Gh., Lorenţ A., Tudoroiu M., Petrilă M., 2010. Regiunile de provenienţă pentru materialele de bază din care se obţin materialele forestiere de reproducere din România [Regions of provenances of basic materials for forest reproductive material in Romania]. Editura Silvică, Bucureşti, 122 p.

Pârnuță Gh., Mihai G., Ștețca I., Petrila M., 2005. Aspecte noi privind stabilirea și delimitarea regiunilor de proveniență pentru materialele forestiere de reproducere din România [New aspects regarding description and demarcation of the regions of provenance for the Romanian Forest Reproductive Materials]. Anale ICAS 48: 27-43.

Pastorelli R., Smulders M.J.M., Van’t Westende W.P.C., Vorman B., Giannini R., Vettori C., Vendramin G.G., 2003. Characterization of microsatellite markers in $\mathrm{Fa}$ gus sylvatica L. and Fagus orientalis Lipsky. Molecular Ecology Notes 3: 76-78.

Paule L., 1995. Gene conservation in European beech ( $\mathrm{Fa}$ gus sylvatica L.). Forest Genetics 2(3): 161-170.

Paule L., Gömöry D., Longauer R., Krajmerova D., 2002. Patterns of genetic diversity distribution in three main Central European montane tree species: Picea abies Karst., Abies alba Mill. and Fagus sylvatica L. Lesnícky časopis 47(2): 153-163.

Peakall R., Smouse P.E., 2012. GenAlEx 6.5: genetic analysis in Excel. Population genetic software for teaching and research-an update. Bioinformatics (Oxford, England) 28: 2537-2539.

Petit R.J., Aguinagalde I., de Beaulieu J.L., Bittkau C., Brewer S., Cheddadi R., Ennos R., Fineschi S., Grivet D, Lascoux M., Mohanty A., Müller-Stark G., Demesure-Musch B., Palme A., Martin J.P., Rendell S., Vendraminn G.G., 2003. Glacial refugia: hotspots but not melting pots of genetic diversity. Science 300: 15631565.

Popescu F., Postalache D., 2009. Markeri ADNcp [cpDNA markers]. In: Georgeta Mihai (ed.), Surse de seminţe testate pentru principalele specii de arbori forestieri din România [Tested seed sources for the main forest tree species from Romania]. Editura Silvica, București, pp. 208, 215, 220.

Pritchard J.K., Stephens M., Donnelly P., 2000. Inference of population structure using multilocus genotype data. Genetics 155(2): 945-959.

Rajendra K.C., Seifert S., Prinz K., Gailing O., Finkeldey R., 2014. Subtle human impacts on neutral genetic diversity and spatial patterns of genetic variation in European beech (Fagus sylvatica). Forest Ecology and Management 319: 138-149.

Stănescu V., 1979. Dendrologie [Dendrology]. Editura Didactică și Pedagogică, București, p. 267.

Starke R., 1996. Genetische Aspekte der Reproduction der Buche (Fagus sylvatica L.) unter Berücksichtigung waldbaulicher Gegebenheiten. Berichte des Forschungszentrums Waldökosysteme, Reihe A, Bd. 135, pp. 103.

Sulkowska M., Gömöry D., Paule L., 2012. Genetic diversity of European beech in Poland estimated on the basis of isoenzyme analyses. Folia Forestalia Polonica 54 series A: $48-55$.

Szasz-Len A.M., 2016. Evaluarea diversității genetice a fagului european (Fagus sylvatica L.) în arborete surse de semințe din Munții Carpați [Evaluation of genetic diversity of European beech (Fagus sylvatica L.) in seed source stands in the Carpathian Mountains]. USAMV Cluj-Napoca, Ph.D. Thesis, pp. 174. 
Takezaki N., Nei M., Tamura K., 2014. POPTREEW: Web version of POPTREE for constructing population trees from allele frequency data and computing some other quantities. Molecular Biology and Evolution 31(6): 1622-1624.

Tanaka K., Tsumura Y., Nakamura T., 1999. Development and polymorphism of microsatellite markers for Fagus crenata and the closely related species, $F$. japonica. Theoretical and Applied Genetics 99: 11-15.

Tanțău I., Feurdean A., de Beaulieu J.L., Reille M., Fărcaș S., 2011. Holocene vegetation history in the upper forest belt of the Eastern Romanian Carpathians. Palaeogeography, Palaeoclimatology, Palaeoecology 309(3-4): 281-290

Tanțău I., Reille M., de Beaulieu J.L., Fărcaș S., 2006. Late Glacial and Holocene vegetation history in the southern part of Transylvania (Romania): pollen analysis of two sequences from Avrig. Journal of Quaternary Science 21(1): 49-61.

Tanţău I., Reille M., de Beaulieu J.L., Fărcaş S., Brewer S., 2009. Holocene vegetation history in Romanian Subcarpathians. Quaternary Research 72(2): 164-173.

Tröber U., Brandes E., 2004. Genetic structures of adult European beech (Fagus sylvatica) stands and the cor- responding natural regeneration in the middle Ore Mountains - Pt 1: Isoyzme gene markers. In: Fürst C. (ed.), Sustainable Methods and Ecological Processes of a Conversion of Pure Norway Spruce and Scots Pine stands into Ecologically Adapted Mixed Stands. Forstwissenschaftliche Beiträge Tharandt 20: 121-130.

Van Oosterhout C., Hutchison W.F., Wills D.P.M., Shipley P., 2004. Micro-checker: Software for identifying and correcting genotyping errors in microsatellite data. Molecular Ecology Notes 4: 535-538.

Vornam B., Decarli N., Gailing O., 2004. Spatial distribution of genetic variation in a natural beech stand (Fagus sylvatica L.) based on microsatellite markers. Conservation Genetics 5: 561-570.

Weir B.S., Cockerham C.C., 1984. Estimating F-Statistics for the analysis of population structure. Evolution 38(6): 1358-1370.

Ziehe M., Vornam B., Müller-Starck G., Turok J., Hattemer H.-H., Maurer W.D., Tabel W., 2002. Genetische Struktur der Buche in Rheinland-Pfalz [Genetic structure of beech in Rhineland-Palatinate]. Mitteilungen aus der Forschungsanstalt für Waldökologie und Forstwirtschaft Rheinland-Pfalz 49: 99-119. 